\title{
МОДЕЛИ ГОСУДАРСТВЕННОЙ ЭКОНОМИЧЕСКОЙ ПОЛИТИКИ СОЗДАНИЯ И РАЗВИТИЯ РЕГИОНАЛЬНЫХ ИНТЕГРАЦИОННЫХ МЕЖГОСУДАРСТВЕННЫХ ОБЪЕДИНЕНИЙ СТРАН С РАЗВИВАЮЩИМИСЯ РЫНКАМИ
}

\author{
(C) 2019 Бу Тун \\ стажер кафедры Экономической теории и менеджмента \\ Московский педагогический государственный университет, Россия, Москва \\ E-mail: Chairt.etm@bk.ru
}

В статье выделяются репродуктивная и продуктивная модели государственной экономической политики создания и развития региональных интеграционных межгосударственных объединений стран с развивающимися рынками, определяются их основные черты. Продуктивная модель охарактеризована как наиболее перспективная в процессе выбора моделей государственной интеграционной экономической политики. Автор выявляет новые формы интеграционного взаимодействия стран с развивающимися рынками, связанные реализацией инвестиционных инфраструктурных проектов «Один пояс и один путь».

Ключевые слова: модели экономической интеграционной политика, продуктивная модель, репродуктивная модель, интеграция, региональные межгосударственные объединения, ЕАЭС, ШОС, проекты «Один пояс и один путь».

Региональная экономическая интеграция является одним из наиболее динамичных экономических явлений в современном мире, и представляет собой многомерный феномен развития экономического пространства стран с развивающимися рынками, объединяющие свои ресурсы в рамках экономических объединений, группировок и союзов, а также международных межправительственных организаций и партнерств (Шанхайская организация сотрудничества-ШОС, Евразийский экономический союз - ЕАЭС, БРИКС и др.).

В последние годы практика региональной экономической интеграции способствует быстрому развитию мировой экономики и формирует основы новой мировой экономической модели, о необходимости которой заявляли практически все участники 23-го Петербургского международного экономического форума (2019). Так, в своей речи Председатель КНР Си Цзиньпин высказал убеждение в том, что «современный мир переживает невиданные за столетия глубокие перемены. Темпы роста стран с формирующимся рынком и развивающихся стран беспрецедентны. Небывалые темпы и острая конкуренция разворачиваются на фоне нового витка научно-технической революции и промышленных преобразований» [2].

Китайские экономисты, теоретически обобщая изменения в структуре мировой экономике и исследуя региональные процессы на международном уровне, пришли к выводу о том, что после окончания «холодной войны» изменения в геополитической обстановке толкали страны на поиск новой международной экономической системы взаимодействия стран с формирующимися рынками. Интернационализация международной многосторонней торговой системы, инвестиций и производства, осуществляемая и подвигаемая ВТО, а также глобальная торговля, возглавляемая транснациональными корпорациями, в совокупности способствовали преобразованию основных форм организации мировой экономики. В то же время технический прогресс, характеризующийся изменением структуры промышленного пространства и появлением новых точек экономического роста, создал новую региональную пространственную структуру [5]. Эти изменения, с одной стороны, открывают новые возможности для развития региональной экономической интеграции и получения экономических выгод мегарегионами на основе использования преимуществ интеграции каждой страной, а, с другой стороны, создают дополнительные вызовы и противоречия. Эти процессы вызвали в начале 2000-х годов новую волну регионализма: если по данным ВТО в 1999 г. действовало 72 региональных торговых соглашений различных типов, то в 2009 г. - уже 201 [7].

Углубление анализа государственной эко- 
номической политики развития интеграционных межгосударственных объединений стран с развивающимися рынками должно идет, понашему мнению, в направлении выделения ее основных моделей. Данной проблематике экономистами не уделяется должного внимания. В основном исследователями характеризуются модели экономической политики в области создания и развития интеграционных объединений, исходя из стадий интеграции и развития торгово-экономических, инвестиционно-промышленных и валютных отношений внутри межгосударственных интеграционных образований (торговля на основе преференциальных соглашений, зона свободной торговли, таможенный союз, общий рынок, валютный союз). Такой подход, имеющий в основании теорию Б.Балассы («лестница интеграции») правомерен, но должен быть дополнен и развит с учетом факторов результативности, инновационности, а также невозможности копирования (воспроизведения) даже успешных для других стран практик государственной интеграционной политики.

В общеметодологическом плане под моделью понимается теоретический конструкт, отражающий экономические явления, процессы, отношения и их взаимодействия с помощью логических описаний и/или количественных параметров. Любая модель экономической политики в этом смысле представляет собой ее упрощенное схематическое описание определенными познавательными средствами, которое для целей исследования может быть дополнено необходимыми элементами. Моделирование экономической политики в отношении любых экономических феноменов, объектов и субъектов тесно связано не только с описанием наличного состояния экономической политики, но и с прогнозированием ее характеристик и направлений дальнейшего развития. Исходя из анализа имеющихся практик и перспектив государственной экономической политики, проводимой стремящимися к интеграции странами, а также опираясь на деятельностную методологическую концепцию, можно выделить две модели государственной экономической политики создания и развития интеграционных объединений стран с развивающимися рынками, а именно - репродуктивную и продуктивную.

Репродуктивная модель государственной экономической политики создания и развития интеграционных объединений стран с развива- ющимися рынками предполагает повторение и мультиплицирование ранее известных практик проведения интеграционной политики государствами, которые уже имеют значительный опыт создания интеграционных объединений. В этом случае страны с развивающимися рынками могут пойти по пути «слепого» воспроизведения методов и способов проведения данной политики, например, странами Европейского Союза, которые накопили значительный опыт движения по «лестнице интеграции» (Б. Баласса). Нами разделяется позиция экономистов, согласно которой «копирование (калькирование) социально-экономических моделей как успешных для конкретных стран является, очевидно, тупиковой ветвью в движении общества» [3, с.202]. Кроме того, репродуктивная модель экономической интеграционной политики воспроизводит систему зависимости от наиболее развитых в экономическом отношении стран, их доминирования в экономических взаимоотношениях с участниками других региональных объединений, что приводит к консервации их экономической отсталости и становлению догоняющего типа развития стран с развивающимися рынками.

Изучение элементов репродуктивной модели государственной экономической политики создания и развития интеграционных объединений стран в глобальной экономике имеет позитивные результат, поскольку дает возможность извлекать уроки из неудачных интеграционных практик, избегать повтора тупиковых вариантов решения задач интеграционного развития и находить оптимальные направления построения интеграционных образований с учетом специфики и потребностей каждой страны-участницы интеграционного образования. В этом случае снизится цена «проб и ошибок» как стоимости политических и экономических издержек. В то же время страны с развивающимися рынками будут иметь преимущество во времени создания эффективных интеграционных институтов, снизив операционные издержки и способствуя, тем самым, экономическому росту. Опыт более продвинутых по пути интеграции экономических межгосударственных объединений, союзов и партнерств может способствовать интенсификации интеграционных процессов, ускоренному прохождению этапов интеграции и развитию институтов интеграции в интеграционные образования стран с развивающимися рынками [4]. 
Интеграционные практики развитых интеграционных союзов дают интеграционным объединений стран с развивающимися рынками определенный прогноз относительно перспектив их развития. На этом основании интеграционные объединения стран с развивающимися рынками могут разработать четкие стратегии для того, чтобы справиться с будущими вызовами, рисками и барьерами.

Продуктивная модель экономической политики создания и развития интеграционных объединений стран с развивающимися рынками указывает на то, что в современной экономике политика государства в отношении всех субъектов и институтов, действующих в интегрируемом экономическом пространстве, должна быть нацелена на обеспечение инновационного развития и продуктивной деятельности государств-участниц интеграционных объединений, группировок, союзов, партнерств.

Продуктивная модель экономической политики создания и развития интеграционных объединений стран с развивающимися рынками обеспечивает новый тип равноправных экономических отношений, развитие инновационных механизмов государственного регулирования в рамках интеграционного экономического пространства, создание инновационных производств товаров и услуг на основе межстранового разделения труда и кооперации (инновационный тип развития стран с развивающимися рынками).

С точки зрения развития региональной экономической интеграции инновационный технологический потенциал может рассматриваться как движущая сила продуктивной модели экономической политики в области создания и развития интеграционных межгосударственных объединений, формируя и обеспечивая конкурентное преимущество мегарегиону, на экономическом пространстве которого происходит поэтапный процесс интеграции.

Продуктивная модель государственной экономической политики направлена на обеспечение функционирования стратегической модели технологических инноваций для ускорения регионального интеграционного развития, что предполагает выявление следующих ее черт и характеристик: во-первых, передовая наука и техника являются основным движущим фактором развития региональной экономической интеграции; во-вторых, технологические и наукоемкие отрасли являются ведущими от- раслями в развитии региональной экономической интеграции; в-третьих, разработка, исследование и производство новых технологий и новой продукции являются отличительными чертами технологических инноваций региональной экономической интеграции; в-четвертых, страны-участники и все экономические агенты в рамках региональной экономической интеграции являются основными субъектами технологических, управленческих и маркетинговых инноваций; в-пятых, университеты и научно-исследовательские учреждения, совместно созданные в рамках региональной экономической интеграции, играют важную роль в реализации стратегической модели технологического инновационного развития интеграционных объединений стран с развивающимися рынками.

Стратегическая модель инновационных и прорывных технологий занимает центральное место в продуктивной модели экономической политики создания и развития интеграционных объединений стран с развивающимися рынками, обеспечивая взаимное сотрудничество, генерирование синергетического эффекта взаимодействия между различными институтами интеграции, эффективное сочетание инновационных факторов производства, постоянное наращивание инновационного потенциала, приобретение и поддержание глобальной конкурентоспособности стран-участниц интеграционного образования стран с развивающимися рынками.

Эффективный инновационный механизм продуктивной модели экономической политики развития интеграционных образований стран с развивающимися рынками направлен на укоренение и развитие институтов интеграции и устранения противоречий и трений, возникающих во внутренней и внешней среде функционирования интеграционного межгосударственного образования под влиянием объективных и субъективных факторов.

К одному из основных элементов инновационного механизма продуктивной модели экономической политики развития региональных интеграционных образований стран с развивающимися рынками следует отнести многоуровневый и многообразный координационный механизм, обеспечивающий направленность действий государств-участников на достижение стратегических целей интеграционного образования, которые поименованы в ее учредительных документах. Так, ЕАЭС в «Договоре о 
Евразийском экономическом союзе» в качестве основных целей выдвигает создание условий для стабильного развития экономик государств-членов в интересах повышения жизненного уровня их населения; стремление к формированию единого рынка товаров, услуг, капитала и трудовых ресурсов в рамках Союза; всестороннюю модернизацию, кооперацию и повышение конкурентоспособности национальных экономик в условиях глобальной экономики [1].

В «Декларации о создании ШОС», которая является постоянно действующей региональной международной организацией стран с развивающимися рынками, определены такие цели, как укрепление взаимного доверия, дружбы и добрососедства; поощрение эффективного сотрудничества; совместные усилия по поддержанию и обеспечению мира, безопасности и стабильности в регионе, построению нового демократического, справедливого и рационального политического и экономического международного порядка. Несмотря на то, что участники «Шанхайской пятерки», как политической организации, созданной в 1996 г., значительно продвинулись на пути интеграции, учредив ШОС (2001), у стран-участников ШОС наличествуют только предпосылки формирования модели экономической политики в отношении ШОС как регионального экономического межгосударственного объединения. Вместе с тем, при углублении процессов экономической интеграции и развитии институтов интеграции в ШОС важно изначально создавать продуктивную модель интеграционной политики и не воспроизводить в будущем репродуктивные элементы экономической деятельности. В этом отношении необходимо поддержать позицию Председателя КНР Си Цзиньпина, который отметил то, что надо непрерывно привносить инновационные политики, продвигать экономические структурные реформы, чтобы создать пространство для экономического роста, повышение выносливости [7].

Теоретическое описание двух моделей государственной экономической политики создание и развития региональных экономических объединений стран с развивающимися рынками позволяет определить перспективу интеграционных межгосударственных объединений и блокировать формирование неэффективной модели интеграционной политики. Однако в настоящее время страны с развивающимися рынками все больше используют не классическое формы региональных торговых соглашений, одобренных к заключению правилами ВТО (Coглашение о свободной торговле, Таможенный союз, Соглашение об экономической интеграции, Соглашение о частичных сферах действия), а новые формы объединений своих усилий и ресурсов в области политического, финансового и социально-экономического сотрудничества. К таким формам межгосударственного взаимодействия можно отнести не только партнерство БРИКС (Бразилия, Россия, Индия, Китай, Южная Африка), но многосторонние инновационные проекты, как новую форму интеграционного взаимодействия стран с развивающимися рынками.

В 2013 году Китай выдвинул амбициозный проект «Нового шёлкового пути» (НШП) под лозунгом «Один пояс и один путь», который предполагает реализацию двух капиталоемких проектов - «Экономический пояс Шёлкового пути» и «Морской Шёлковый путь XXI века». Это инфраструктурные проекты направлены на создание обширной транспортно-логистической сети от западных границ Китая через страны Средней Азии и Иран в Европу. Сопряжение экономической деятельности ЕАЭС и НШП создает новую форму интеграционных межгосударственных взаимосвязей и взаимодействия стран с развивающимися рынками на огромном экономическом пространстве Евразии.

Подписанное в 2015 году «Совместное заявление Российской Федерации и Китайской Народной Республики о сотрудничестве по сопряжению строительства Евразийского экономического союза и Экономического пояса Шелкового пути» создало условия для построения диалогового механизма между представителями заинтересованных ведомств, который можно рассматривать как новацию и элемент продуктивной модели экономической региональной интеграционной политики.

Таким образом, рассмотрение моделей государственной экономической политики создания и развития региональных интеграционных межгосударственных объединений стран с развивающимися рынками позволило выделить не только продуктивную модель в качестве наиболее перспективной в процессе выбора моделей государственной интеграционной экономической политики, но и выявить новые формы интеграционного взаимодействия стран с развивающимися рынками. 


\section{Библиографический список}

1. Договор о Евразийском экономическом союзе. URL: https://docs.eaeunion.org/ru-ru/Pages/DisplayDocument. aspx

2. Пленарное заседание Петербургского международного экономического форума. URL: http://www.kremlin. ru/events/president/news/60707 (30.08.2019)

3. Платонова Е.Д. Современная теория и практика накопления / под.ред.д.э.н. Е.В. Юферевой - М.: Изд-во АПКиППРО, 2006. 368 с.

4. Сунь Юймэн, Платонова Е.Д. Этапы эволюции институтов в экономическом пространстве региональных межгосударственных объединений (теоретический аспект) // Интернет-журнал «НАУКОВЕДЕНИЕ» Том 9, № 4. 2017. URL: http://naukovedenie.ru/PDF/96EVN417.pdf

5. 王玨, 陈雯. 全球化视角的区域主义与区域一体化理论阐释 [J]. 地理科学进展. 2013年, 第 32 卷, 第7 期, 第1084 页 [Ван Юй, Чэнь Вэнь. Разъяснение регионализма и региональной интеграции с точки зрения глобализации// Географический научный прогресс. 2013, Том 32, № 7, с. 1084]

6. 习近平拿出打开世界经济增长和发展瓶颈的钥匙, 学习中国, 中国评论新闻网, 02, 2017。 [Си Цзиньпин. Ключ для открытия мирового экономического роста, расшивки узких мест и изучения Китая//Китайский обзор новостей. 02. 2017]

7. Regional trade agreements. URL: http://rtais.wto.org/UI/charts.aspx (Date of access: 30.08.2019) 